\title{
A comparative study of respiratory function in female non-smoking cotton and jute workers
}

\author{
F. VALIC and EUGENIJA ŽUŠKIN \\ Department of Occupational Health, Andrija Stampar School of Public Health, Medical \\ Faculty, Zagreb University, Zagreb, Yugoslavia
}

\begin{abstract}
Valić, F., and Žuškin, E. (1971). Brit. J. industr. Med., 28, 364-368. A comparative study of respiratory function in female non-smoking cotton and jute workers. To compare the effect of cotton and jute dust, respiratory symptoms were studied and respiratory function measured in 60 cotton and 91 jute non-smoking female workers of similar age distribution, similar length of exposure to dust, and exposed to similar respirable airborne dust concentrations. Cotton workers had a significantly higher prevalence of byssinosis, of persistent cough, and of dyspnoea $(P<0.01)$ than jute workers. Among cotton workers $28.3 \%$ were found to have characteristic symptoms of byssinosis, whereas none was found among jute workers.

Exposure to cotton but also to jute dust caused significant reductions of $\mathrm{FEV}_{\mathbf{1 . 0}}, \mathrm{FVC}$, and PEF $(P<0.01)$ over the first working shift in the week. Functional grading of jute and cotton dust effects has shown that about $30 \%$ of cotton workers had functional grades $\mathrm{F} 1$ and $F 2$, while only $13 \%$ of jute workers were found in the same grades (F1). It is concluded that cotton dust may be considered more active than jute though the latter cannot be considered inactive.
\end{abstract}

It is well known that exposure to cotton dust may cause respiratory symptoms, including the characteristic byssinosis symptoms of chest tightness on the first working day after absence from work, accompanied by changes of ventilatory function. Much less is known about the respiratory effects in workers in jute manufacture. Arlidge (1892), Wilson (1902), and Schilling (1956) reported that dust from jute caused chronic respiratory diseases. In a group of 123 jute workers, Mair, Smith, Wilson, and Lockhart (1960) reported on two jute workers who gave histories of cough worse on Mondays, although the characteristic fall in the expiratory flow rate was absent. Twohundred and forty-four workers in a jute mill were interviewed by Siddhu, Nath, and Mehrotra (1966) and none was found to have byssinosis. Popa et al. (1969) reported byssinosis in jute processing.

Gilson et al. (1962) found no significant effect of juiè dust on ventilatory function. Recently, Gandevia and Milne (1965) studied ventilatory capacity in 46 workers exposed to jute dust. A significant mean decrease in the forced expiratory volume in one second was observed on the first day of work.

Owing to a few somewhat conflicting reports on the effects of jute dust on the one hand, and relatively well-known effects of cotton dust on the other, a comparative study was made of the effect of jute and cotton dust in non-smoking textile workers of the same sex, similar age, and similar length of exposure.

\section{Population and methods}

The group examined consisted of 60 female cotton and 91 female jute workers. Only non-smokers were included in the study. The distributions of subjects by length of exposure to cotton and jute dust respectively and by age were not identical but were similar. The average duration 
of exposure to cotton dust was 4 (range 1 to 8 ) years and to jute dust 3 (range 1 to 9) years. Cotton workers were slightly older (mean age 27, range 17 to 41 years) than jute workers (mean age 23 , range 17 to 41 years).

\section{Definitions}

The Medical Research Council questionnaire on respiratory symptoms was used throughout the study with additional questions on byssinosis and occupational histories (Schilling et al., 1963).

Respiratory symptoms were defined as follows:

Persistent cough and/or phlegm: cough and/or phlegm production on most days for at least three months each year

Dyspnoea: grade 3, able to keep on walking at own (slower than average) pace on the level; grade 4 , forced to stop for breath when walking at own slow pace on the level.

Clinical grades of byssinosis: grade $1 / 2$, occasional chest tightness on Mondays; grade 1, chest tightness or difficulty in breathing on every Monday; grade 2, chest tightness or difficulty in breathing during work on Mondays and other working days.

In addition to clinical grading of byssinosis, a functional grading system based on acute and chronic $F E V_{1 \cdot 0}$ changes was used according to the recommendation of Bouhuys, Gilson, and Schilling (1970; Table 3).

\section{Respiratory function tests}

Forced expiratory volume in the first second $\left(\mathrm{FEV}_{1 \cdot 0}\right)$ and forced vital capacity (FVC) were measured in all subjects with a standardized spirometer of the Bernstein type. After a rest of three to four minutes, the peak expiratory flow (PEF) was measured on a Wright peak flowmeter (Wright and McKerrow, 1959). Ventilatory function tests were performed at the beginning and at the end of the first working day after the week-end. Five measurements were taken, and the mean of the two highest values was used as the result. FEV $_{1 \bullet 0}$ and FVC were corrected to B.T.P.S.

The measurements of $\mathrm{FEV}_{1 \cdot 0}$ and PEF were repeated 15 minutes after inhalation of a bronchodilator (orciprenaline $^{1}$ ) at the end of the working shift. Orciprenaline was administered to two groups of volunteers ( 46 cotton workers and 37 jute workers) by a pocket nebulizer. ${ }^{2}$

${ }^{1}$ Alupent: 1-/3,5-Dihydroxyphenyl/-2-isopropylaminoaethanol sulphate.

${ }^{2}$ Alupent and nebulizers were granted by Messrs. C. $\mathbf{H}$. Boehringer Sohn, Ingelheim, Germany.

\section{Dust sampling}

Airborne dust in both mills was sampled in the areas in which the examined workers were employed. The dust was collected by Hexhlet two-stage samplers with a horizontal elutriator to provide total and respirable dust concentrations.

\section{Statistical analyses}

Results of statistical analyses ( $t$-test for testing differences of paired and unpaired variables in the comparison of ventilatory capacity, $\chi^{2}$-test for testing differences of prevalences, Spearman's coefficient of correlation) are considered significant when the probability of obtaining the results by chance alone is less than 0.05 .

\section{Results}

\section{Airborne dust concentrations}

Total and respirable airborne dust concentrations measured in the cotton and the jute mills are presented in Table 1. The results show that the level of exposure was very similar in both mills, especially the respirable fraction.

TABLE 1

Cotton and Jute Dust Concentrations

\begin{tabular}{l|c|cc}
\hline & \multirow{2}{*}{$\begin{array}{c}\text { No. of } \\
\text { samples }\end{array}$} & $\begin{array}{c}\text { Geometric mean of dust concentration } \\
\left(\mathrm{mg} / \mathrm{m}^{3}\right)\end{array}$ \\
\cline { 3 - 4 } & & Total & Respirable \\
\hline Cotton & 27 & 3.39 & 0.95 \\
Jute & 19 & 3.99 & 0.84 \\
\hline
\end{tabular}

${ }^{1}$ The distribution of concentrations was logarithmic. Geometric means are, therefore, calculated rather than arithmetic means.

\section{Respiratory symptoms}

The average prevalence of respiratory symptoms in the examined cotton and jute workers is summarized in Table 2. The findings in the cotton and jute mills differ significantly with regard to the prevalence of byssinosis, persistent cough, and dyspnoea $(\mathbf{P}<$

TABLE 2

Prevalence of Respiratory Symptoms in Cotton and Jute Workers

\begin{tabular}{|c|c|c|c|c|c|c|}
\hline Group & $N$ & $\begin{array}{c}\text { Byssinosis } \\
\%\end{array}$ & $\begin{array}{c}\text { Persistent cough } \\
\%\end{array}$ & $\begin{array}{c}\text { Persistent phlegm } \\
\%\end{array}$ & $\begin{array}{c}\text { Dyspnoea } \\
\text { (grade } 3+4) \\
\%\end{array}$ & $\begin{array}{c}\text { Nasal catarrh } \\
\%\end{array}$ \\
\hline $\begin{array}{l}\text { Cotton } \\
\text { Jute }\end{array}$ & $\begin{array}{l}60 \\
91\end{array}$ & $\begin{array}{c}28.3 \\
<0.01 \\
0\end{array}$ & $\begin{array}{c}30.0 \\
<0.01 \\
9.8\end{array}$ & $\begin{array}{c}23 \cdot 3 \\
\text { NS } \\
13 \cdot 2\end{array}$ & $\begin{array}{c}11.7 \\
<0.01 \\
1.1\end{array}$ & $\begin{array}{c}46 \cdot 7 \\
\text { NS } \\
31 \cdot 9\end{array}$ \\
\hline
\end{tabular}

NS $=$ not significant $(P>0.05)$ 
0.01). Dyspnoea grade 3 or 4 was found in $11.7 \%$ of cotton workers $(10.0 \%$ grade $3 ; 1.7 \%$ grade 4$)$ and in $1.1 \%$ of jute workers (all grade 3 ). The prevalence of persistent phlegm and nasal catarrh was higher in the cotton than in the jute workers, but the differences were not statistically significant. None of the interviewed jute workers had characteristic symptoms of byssinosis.

Classified according to the clinical grading system, byssinosis grade $\frac{1}{2}$ was found in $11.7 \%$ of cotton workers, grade 1 in $13.3 \%$, and grade 2 in $3.3 \%$. Subjects with symptoms of byssinosis had a higher prevalence of persistent cough $(41.2 \%)$, persistent phlegm $(29.4 \%)$, and nasal catarrh $(64.7 \%)$ than those without byssinosis $(25.6 \%, 20.9 \%$, and $39.5 \%$ respectively), but the differences were not statistically significant.

The distribution of byssinotics by grade of byssinosis and by length of exposure has shown that grades $\frac{1}{2}$ and 1 may develop after only one year of exposure but development of grade 2 took eight years' exposure to cotton dust.

\section{Ventilatory function tests}

Exposure to cotton dust as well as to jute dust was associated with a statistically significant fall in FEV $_{1.0}, \mathrm{FVC}$, and PEF during the first working day (Table 3). The mean reductions in jute workers were lower than those in cotton workers but were still significant. Cotton workers had a significantly greater decrease in FVC $(P<0.01)$ and PEF $(P<0.05)$ than the jute workers. No significant difference was found in $\mathrm{FEV}_{\mathbf{1 . 0}}$ reduction between these two groups, A significant decrease of $\mathrm{FEV}_{\mathbf{1 . 0}}$, FVC, and PEF on the first working day occurred both in those who gave a history of Monday dyspnoea and in those who did not.

The measurements of FEV $_{1.0}$ and PEF in jute workers with and without respiratory symptoms (persistent cough, persistent phlegm or dyspnoea) have shown greater mean reductions over the shift in FEV $_{1.0}(-159 \mathrm{ml})$ and PEF $(-201 / \mathrm{min})$ in subjects with respiratory symptoms than in those without these symptoms $\left(\mathrm{FEV}_{\mathbf{1 . 0}}-114 \mathrm{ml}\right.$; PEF $-131 / \mathrm{min}$ ), but the differences were not statistically significant. Cotton workers with respiratory symptoms including byssinosis also had greater mean reductions in $\mathrm{FEV}_{1.0}$ and PEF $(-171 \mathrm{ml} ;-28$ $1 / \mathrm{min})$ than those without such symptoms $\left(\mathrm{FEV}_{1.0}\right.$ $-121 \mathrm{ml}$; PEF $-211 / \mathrm{min}$ ). The differences were not significant.

Bouhuys et al. (1970) have suggested a grading system which includes an assessment of acute and chronic effects of textile dust on ventilatory capacity. The predicted FEV $_{1.0}$ values were calculated from the nomogram for the female normal population of the Veterans Administration-Army Cooperative Study (Kory, Smith, and Callahan, in preparation). The results of functional grading in cotton and jute workers are presented in Table 4 . Almost $30 \%$ of

TABLE 3

Mean FEV $_{1.0}$, FVC, and PEF Changes in Cotton and Jute Workers over Work Shift

\begin{tabular}{|c|c|c|c|c|c|c|c|c|c|c|}
\hline \multirow{2}{*}{ Group } & \multirow{2}{*}{$N$} & \multicolumn{3}{|c|}{$F E V_{1 \cdot 0}$} & \multicolumn{3}{|c|}{$F V C$} & \multicolumn{3}{|c|}{$P E F$} \\
\hline & & $m l$ & $\%$ & $\mathbf{P}$ & $m l$ & $\%$ & $\mathbf{P}$ & $l / \min$ & $\%$ & $\mathbf{P}$ \\
\hline Cotton & 60 & $\begin{array}{c}-138 \\
\text { NS }\end{array}$ & $-4 \cdot 1$ & $<0.01$ & $\begin{array}{l}-108 \\
<0.01\end{array}$ & $-2 \cdot 7$ & $<0.01$ & $\begin{array}{c}-23 \\
<0.05\end{array}$ & $-5 \cdot 1$ & $<0.01$ \\
\hline Jute & 91 & -121 & $-3 \cdot 8$ & $<0.01$ & -57 & -1.5 & $<0.01$ & -15 & $-3 \cdot 5$ & $<0.01$ \\
\hline
\end{tabular}

NS $=$ not significant $(P>0.05)$

TABLE 4

Functional Grades ${ }^{1}$ of Cotton and Jute Dust Effects

\begin{tabular}{|c|c|c|c|c|c|c|}
\hline & $\begin{array}{l}\text { Functional } \\
\text { grades }\end{array}$ & & $\begin{array}{c}\Delta F E V_{1 \cdot 0} \\
(\text { litres })\end{array}$ & $\begin{array}{c}F E V_{1 \cdot 0} \\
(\% \text { of predicted })^{2}\end{array}$ & $\begin{array}{c}\text { Cotton }(\mathrm{N}=60) \\
\%\end{array}$ & Jute $\underset{\%}{(\mathrm{M}}=91)$ \\
\hline $\begin{array}{l}F \\
F \\
F \\
F \\
F\end{array}$ & $\begin{array}{l}\ldots \\
\cdots \\
\cdots \\
\cdots \\
\cdots\end{array}$ & $\begin{array}{l}\cdots \\
\cdots \\
\cdots \\
\cdots \\
\cdots\end{array}$ & $\begin{array}{c}-0.05-0 ; \text { or }+ \\
-0.06--0.20 \\
>--0.20 \\
\ldots \\
\ldots\end{array}$ & $\begin{aligned}> & 80 \\
> & 80 \\
> & 80 \\
& 60-79 \\
< & 60\end{aligned}$ & $\begin{array}{c}28 \cdot 3 \\
41 \cdot 6 \\
28 \cdot 3 \\
1 \cdot 6 \\
0\end{array}$ & $\begin{array}{c}29 \cdot 6 \\
57 \cdot 1 \\
13 \cdot 1 \\
0 \\
0\end{array}$ \\
\hline
\end{tabular}

${ }^{1}$ Bouhuys et al. (1970)

${ }^{2}$ Using the nomogram for normal females from the Veterans Administration Army Co-operative Study (Kory et al., in preparation) 
TABLE 5

MeAN FEV $_{1.0}$ AND PEF Changes after Inhalation of Bronchodilator at END of Work ShIFT

\begin{tabular}{|c|c|c|c|c|c|c|c|}
\hline Group & Test & $\begin{array}{c}\text { Before } \\
\text { work } \\
1\end{array}$ & $\begin{array}{c}\text { After } \\
\text { work } \\
2\end{array}$ & $\begin{array}{c}\text { Difference } \\
1-2 \\
\mathbf{P}\end{array}$ & $\begin{array}{c}\text { After } \\
\text { bron- } \\
\text { chodilator } \\
3\end{array}$ & $\begin{array}{c}\text { Difference } \\
2-3 \\
\mathbf{P}\end{array}$ & $\begin{array}{c}\text { Difference } \\
1-3 \\
\mathbf{P}\end{array}$ \\
\hline $\begin{array}{l}\text { Cotton } \\
\mathbf{N}=46\end{array}$ & $\begin{array}{l}\mathrm{FEV}_{1 \cdot 0} \\
(\mathrm{ml}) \\
\mathrm{PEF} \\
(\mathrm{l} / \mathrm{min})\end{array}$ & $\begin{array}{r}3277 \\
449\end{array}$ & $\begin{array}{r}3138 \\
423\end{array}$ & $\begin{array}{l}<0.01 \\
<0.01\end{array}$ & $\begin{array}{r}3290 \\
448\end{array}$ & $\begin{array}{l}<0.01 \\
<0.01\end{array}$ & $\begin{array}{l}\text { NS } \\
\text { NS }\end{array}$ \\
\hline $\begin{array}{l}\text { Jute } \\
\mathbf{N}=37\end{array}$ & $\begin{array}{l}\mathrm{FEV}_{1 \cdot 0} \\
(\mathrm{ml}) \\
\mathrm{PEF} \\
(\mathrm{l} / \mathrm{min})\end{array}$ & $\begin{array}{r}3101 \\
422\end{array}$ & $\begin{array}{r}2981 \\
407\end{array}$ & $\begin{array}{l}<0.01 \\
<0.01\end{array}$ & $\begin{array}{r}3098 \\
424\end{array}$ & $\begin{array}{l}<0.01 \\
<0.01\end{array}$ & $\begin{array}{l}\text { NS } \\
\text { NS }\end{array}$ \\
\hline
\end{tabular}

cotton workers had dust effects of functional grades F1 and F2, while only $13 \%$ of jute workers were found in the same grades (F1 only).

The results of ventilatory function tests after inhalation of the bronchodilator at the end of the working shift are presented in Table 5. There were significant reductions of FEV $_{1.0}$ and PEF $(P<0.01)$ over the work shift. These acute reductions during dust exposure proved to be reversible on administration of the bronchodilator. Actually, the mean $\mathrm{FEV}_{1.0}$ and mean PEF were increased to their initial pre-shift values after the inhalation of orciprenaline. No difference was revealed by statistically comparing the values measured after orciprenaline inhalation at the end of work with those recorded before the work shift.

In this group 22 cotton workers (48\%) and 11 jute workers $(30 \%)$ had respiratory symptoms. Separate analysis of the bronchodilator effect in cotton workers with and without respiratory symptoms has shown slightly greater improvement of $\mathrm{FEV}_{1.0}$ on inhalation of orciprenaline after the shift in workers who had respiratory symptoms $(+6 \%)$ than in those without respiratory symptoms $(+3 \%)$ in relation to the values after the work shift. PEF improved to the same degree in both groups $(+6 \%)$. In jute workers with and without respiratory symptoms both FEV $_{1.0}$ and PEF increased by $4 \%$.

\section{Discussion}

None of the jute workers interviewed was found to have symptoms of byssinosis. These findings are in conformity with those of Schilling (1956), Mair et al. (1960), and Siddhu et al. (1966). In his experimental studies, Nicholls (1962) investigated the level of contractor activity of cotton, hemp, flax, jute, and sisal dust extracts and found it to be the lowest in jute dust.
Nevertheless, according to our results, jute dust may cause persistent cough and persistent phlegm. In a control group of 60 non-smoking female workers of similar age distribution, with no dust exposure, prevalence of persistent cough and persistent phlegm was found to be significantly lower $(P<0.05)$ than in our jute workers (Zuškin, 1967). Mair et al. (1960) reported a prevalence of chronic bronchitis in female jute workers $(11 \%)$ similar to that found in our study (persistent cough $9.8 \%$; persistent phlegm $13.2 \%$ ). Our data are also in agreement with those of Schilling (1956) who in a group of 20 jute workers found a $10 \%$ prevalence of chronic bronchitis.

Our results suggest that jute dust, although 'nonbyssinogenic', is capable of causing a decrease in ventilatory capacity over a working day. Subjects with persistent cough and persistent phlegm had significantly higher reductions in $\mathrm{FEV}_{\mathbf{1 . 0}}$ than those without such symptoms. In jute workers Gandevia and Milne (1965) reported a significant mean $\mathrm{FEV}_{1.0}$ decrease $(85 \mathrm{ml})$ on the first working day. The same authors reported in six non-smokers employed for less than a month a significant mean $\mathrm{FEV}_{1.0}$ decrease of $140 \mathrm{ml}$ over the first working shift after the weekend. In our study four workers exposed to jute dust for one or less than one year had a mean $F_{E V}$ reduction over the shift of $109 \mathrm{ml}$.

Our results of ventilatory capacity reductions are in contrast with those obtained in two studies of ventilatory capacity in workers during jute exposure by Mair et al. (1960) and Gilson et al. (1962) who did not find any significant changes in ventilatory capacity during working hours.

Taking into account very similar dust concentrations in both mills, cotton dust appears to be more active in causing respiratory disease and acute lung function changes than jute dust. Yet the effects of jute dust cannot be disregarded. 


\section{References}

Arlidge, J. T. (1892). The Hygiene, Diseases, and Mortality of Occupations. Percival, London.

Bouhuys, A., Gilson, J. C., and Schilling, R. S. (1970). Byssinosis in the textile industry. Arch. environm. Hlth, 21, 475-478.

Gandevia, B., and Milne, J. (1965). Ventilatory capacity on exposure to jute dust and the relevance of productive cough and smoking to the response. Brit.J. industr. Med., 22, 187-195.

Gilson, J. C., Stott, H., Hopwood, B. E. C., Roach, S. A. McKerrow, C. B., and Schilling, R. S. F. (1962). Byssinosis: The acute effect on ventilatory capacity of dusts in cotton ginneries, cotton, sisal, and jute mills. Brit. J. industr. Med., 19, 9-18.

Mair, A., Smith, D. H., Wilson, W. A., and Lockhart, W. (1960). Dust diseases in Dundee textile workers. Brit. J. industr. Med., 17, 272-278.

Nicholls, P. J. (1962). Some pharmacological actions of cotton dust and other vegetable dusts. Brit. J. industr. Med., 19, 33-41.

Popa, V., Gavrilescu, N., Preda, N., Teculescu, D., Plecias,
M., and Cirstea, M. (1969). An investigation of allergy in byssinosis: sensitization to cotton, hemp, flax and jute antigens. Brit. J. industr. Med., 26, 101-108.

Schilling, R. S. F. (1956). Byssinosis in cotton and other textile workers. Lancet, 2, 261-265, 319-324.

, Vigliani, E. C., Lammers, B., Valic, F., and Gilson, J. C. (1964). A report on a Conference on Byssinosis. In Proc. XIV int. Congr. occup. Hlth, Madrid, 1963, vol. 2, pp. 137-145. Excerpta Medica, Int. Congr. Ser. No. 62., Amsterdam.

Siddhu, C. M. S., Nath, K., and Mehrotra, R. K. (1966). Byssinosis amongst cotton and jute workers in Kanpur. Ind. J. med. Res., 54, 980-994.

Wilson, H. J. (1902). Jute. In Dangerous Trades, ed. T. Oliver. Murray, London.

Wright, B. M., and McKerrow, C. B. (1959). Maximum forced expiratory flow rate as a measure of ventilatory capacity, with a description of a new portable instrument for measuring it. Brit. med. J., 2, 1041-1047.

Zuskin, E. (1967). Acute and chronic effects of vegetable dust in industrial exposure. Doctoral Thesis, Zagreb University.

Received for publication January 14, 1971 